\title{
BUSINESS DECISION-MAKING OF TOP MANAGEMENT WHICH IMPLEMENTS BASIC LEGAL STANDARDS AND ADOPTED ACTS IN COMPANIES WITH RESPECT FOR RECOMMENDATIONS OF INTERNAL AUDITORS
}

\author{
Dragan Djuranovic, PIM University Banja Lulka, Despota Stefana Lazarevica bb, Banja Luka, 78000, Bosnia \\ and Herzegovina, gandra.dj@hotmail.com
}

Slobodan Popovic, JKP Gradsko Zelenilo Novi Sad, Mladena Leskovca 1, 21000 Novi Sad, Republic Of Serbia, Corresponding Author, slobodan.popovic49@gmail.com

\begin{abstract}
The legal sector in the company should facilitate the overall management of the top management of the company. In the course of performing its tasks, the legal sector adopts general acts that essentially precede the overall decision-making processes in companies by the top management of the company.

The legal sector performs and establishes cooperation with other sectors in the company, such as: commercial sector, accounting sector, financial, technical and other sectors, but also establishes cooperation with the introduced internal audit of companies.

The legal sector should help the processes of regular business in the company, i.e. the legal sector primarily provides security in the processes of making valid decisions in the processes of normal and regular business of the company primarily on the basis of valid decisions made by top management in companies.

In this paper, the authors gave essential importance to the presentation of real work performed by appointed internal auditors who perform internal audit activities in accordance with numerous laws governing their operations in companies that have appointed internal audit as part of regular operations.

Internal audit must organize its operations that will be essentially in accordance with the adopted professional standards of the audit profession.
\end{abstract}

Key words: business decision making, legal sector, internal audit. 


\section{INTRODUCTORY NOTES REGARDING THE SIGNIFICANCE OF THE ORGANIZATION OF LEGAL IN ENTERPRISES AND INTERNAL AUDIT}

This study highlights the importance of the practical application of the work of the legal sector and internal audit in companies, which builds on the previously published numerous studies that followed the practical business in heterogeneous companies in their essence.

The legal sector in the company provides the basic legal framework in which the company operates [1-5]. The legal sector should help in the interpretation of laws that can significantly affect the business of the company, and at the same time this sector of the company is connected with other sectors in the company. In addition, the legal sector of the company adopts a number of documents that accompany the regular operations of the company and at the same time this sector adopts a number of acts and bylaws in the company [6-10].

In addition, the legal sector in the company is actively associated with the business of internal audit in the companies themselves [11-15].

The authors point out that in the work of the legal sector and internal audit in the company, there must be a rational use in the use of funds necessary for the functioning of the legal sector but also for the functioning of internal audit in the company.

The mentioned tasks should be performed by the legal sector and internal audit in the company in an economical way, i.e. in an efficient and effective way, during the entire process of business and functioning of the company.

The goal of top management is to provide efficient and quality management decisions in the company, and for such a goal it is necessary to have the help of the legal sector as well as other established internal control bodies in the company.

The authors point out that the introduced internal audit can greatly enable the achievement of better business results during the regular operation of the company. This is the right and essential way to improve the management functions in the company, and therefore the effects of management decisions are visible in the short term after the introduction of control measures in the company's operations.

The final effects of such management and decision-making in companies are visible in the financial statements, i.e. in the income statements in each accounting period in which they are made in the company. 


\section{BUSINESS DECISION-MAKING OF TOP MANAGEMENT WHICH IMPLEMENTS BASIC LEGAL STANDARDS AND ADOPTED ACTS IN COMPANIES WITH RESPECT FOR RECOMMENDATIONS OF INTERNAL AUDITORS}

During the performance of regular tasks related to the making of management decisions by the top management in companies, one of the important segments on the basis of which the top management must pay attention is the functioning of the legal sector.

In addition to the importance of the undisputed legal sector, its work should be harmonized with the implementation of activities as well as with the work of internal audit that is formed in companies.

Therefore, the legal sector of the company in cooperation with the internal auditor should take care to work in accordance with the adopted standards of professional responsibility defined in the Articles of Association, adopted regulations, signed code of ethics of all employees and especially the code of ethics signed by the CEO and the company's internal auditor.

The Code of Ethics is signed between the international auditor and the top management in companies in the form of a special document which is introduced in the company's books and is a key document in the work of internal audit in the company. is for top management in the company.

In this paper, the authors present a possible flow from which the existence of interaction or connection between internal audit and the legal sector in the company can be seen.

The authors give an overview of the possible organizational scheme in the form of the illustration in Figure 1. 


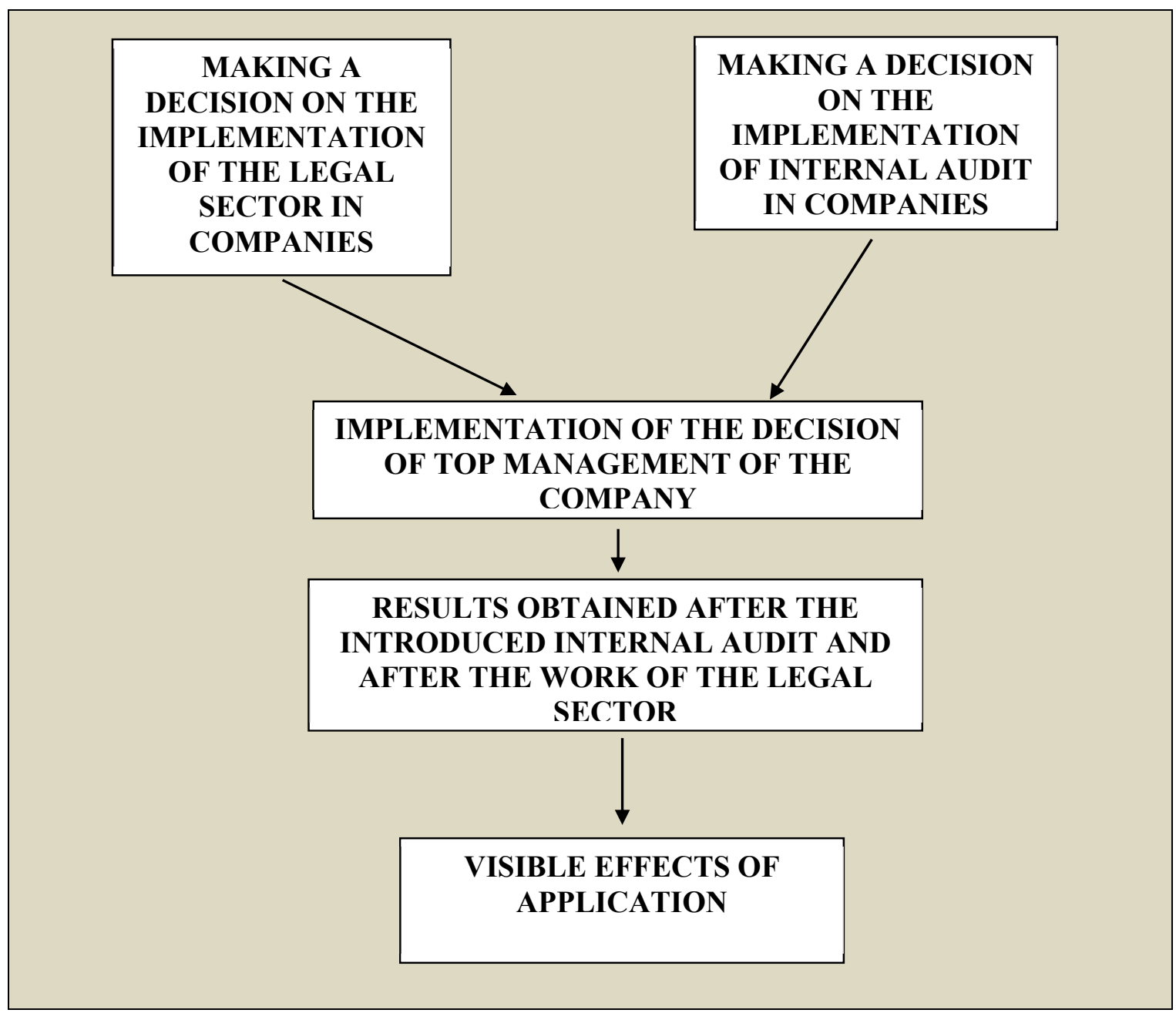

Fig. 1: Overview of the organizational chart after the implementation of the legal sector and the connection with internal audit in the process of management and functioning of top management in companies

\section{ESSENTIAL ACTIVITIES OF INTERNAL AUDIT WITHIN THE MAKING OF POSSIBLE DECISIONS OF TOP MANAGEMENT}

In this study, the authors gave an overview of the most frequently used activities carried out in the work of internal auditors when working on internal audit, and which, based on the authorization of top management, gave them the same on the occasion of performing the tasks entrusted to them. 
In order to get an impression of the most important internal audit activities, the authors systematized the most frequently used activities in performing entrusted internal audit tasks, and gave a presentation of the most common internal audit activities.

The most common activities in the work of internal audit that are entrusted to the internal auditor within the scope of work of internal audit are:

1. Careful planning of each audit,

2. Determine where activities are directed,

3. Consider the risks and their significance,

4. Take care that each audit is adjusted to the circumstances of the company's operations,

5. View each element of the audit as part of the company's operations,

6. Adopt a constructive and positive approach to auditing,

7. Encourage changes in the work of the audited entity,

8. Perform a careful audit review,

9. Provide an independent opinion of the internal auditor,

10. Fulfillment of professional and legal obligations based on the audit of the company,

11. Regularly and appropriately reporting to management on material issues that arose during the preparation of the audit,

12. Make appropriate recommendations for the implementation of corrective measures,

13. Ensure that the audit adequately takes into account all issues identified during the audit and

14. Activities of the top management of the company that it carries out after the internal audit.

An overview of internal audit activities was presented by the authors in the form of Figure 2 . 


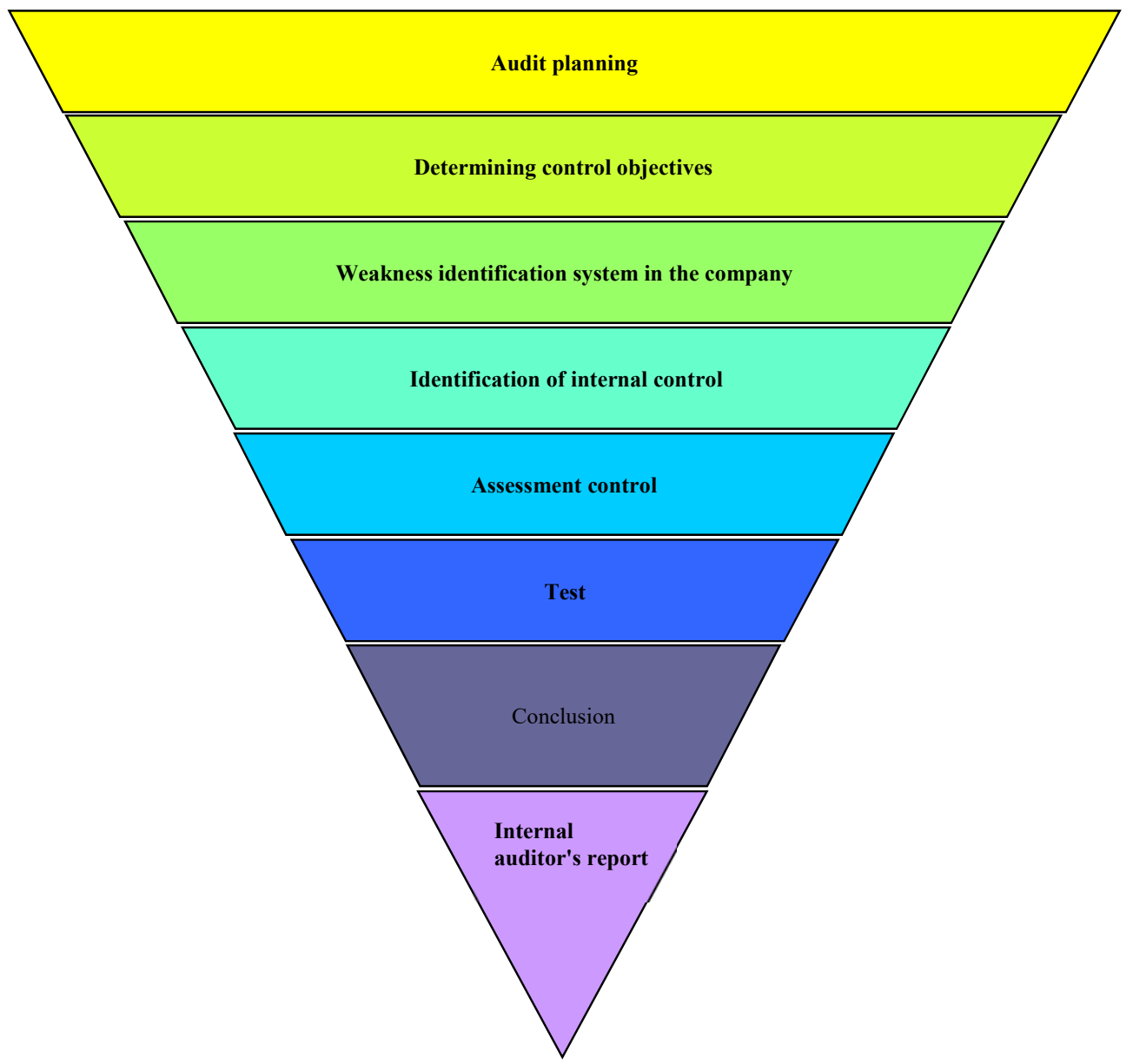

Fig. 2: Overview of the most common tasks in the work of internal audit that operates in the system of overall management by top management in the company.

\section{CONCLUSION}

In this study, the authors presented the importance of the practical application of the legal sector and internal audit within the process of making valid business decisions that are necessary for the operations of top management in companies.

Management by top management largely depends on the management processes established in companies where management and management effects are subject to changes that occur within the legal sector but also within the functioning of internal audit established in companies.

The final result of business and making business decisions brings the result of borrowing, i.e. a measurable result through the achieved financial result in the company. 
Viewed in this way, the management is the one who is interested in achieving a favorable and growing business result of the company.

The study points to the essential connection and importance of the connection between the legal sector and internal audit in the company, all as part of the adoption and realization of a positive financial result of the company's operations.

\section{REFERENCES}

[1] Popović, S., Novaković, S., Đuranović, D., Mijić, R., Grublješić, Ž, Aničić, J., Majstorović, A. (2017). Application of international accounting standard-16 in a public company with predominantly agricultural activities, Economic Research-Ekonomska Istraživanja, 30(1): 1850-1864.

[2] Jokic M., Laban, B., Arnautović, I., Popovic, D. \& Popović S. (2020). The importance of preparing an internal audit report in reporting to top management of a company that makes key management decisions in its work, Annals - Economy Series, Constantin Brancusi University, Faculty of Economics, 2: 37-44.

[3] Mijić, R., Popović, S. (2016). Finansijsko Računovodstvo, Banja Luka: City print.

[4] Majstorović, A., Popović, S., Volf, D. (2015). Teorija i politika bilansa, drugo izmenjeno i dopunjeno izdanje, Novi Sad: Feljton.

[5] Popović, S. (2014). Socio-ekonomski faktori ograničenja razvoja agrara, Monografija, Fimek, Novi Sad, Srbija.

[6] Popović, S., Ugrinović, M., Tomašević, S. (2015). Upravljanje menadžmenta poljoprivrednog preduzeća preko praćenja ukupnih troškova održavanja traktora, Poljoprivredna tehnika, 2: 101-106.

[7] Popović, S., Ugrinović, M., Tomašević, S. (2015). Management of Agricultural Enterprises by Means of Fair Financial Reporting in Accordance with International Standards of the Finance and Accounting Reporting, CDQM, Number 3: 24-30.

[8] Popović, S., Mijić, R., Grublješić, Ž. (2014). Interna kontrola i interna revizija u funkciji menadžmenta. Škola Biznisa, 1, 95-107.

[9] Popović, S., Tošković, J., Majstorović, A., Brkanlić, S., Katić, A. (2015). The importance of continuous audit of financial statements of the company of countries joining the EU, Annals of the „Constantin Brâncuşi” University of Târgu Jiu, Economy Series, Special Issue, 241-246. 
[10] Bojović, R., Popović, V., Ikanović, J., Živanović, Lj., Rakaščan, N., Popović, S., Ugrenović, V \& Simić, D. (2019). Morphological characterization of sweet sorghum genotypes acrossen vironments, The J. Anim. Plant Sci. 29(3).

[11] Popović, S. (2015). Implementacija heterogenih rizika u radu interne revizije, Revizor 69.

[12] Vitomir, J., Tomaš-Miskin, S., Ivić, M., Popović, S. (2020). Implementation of the Tender by the Municipal Service Administration from the Aspect of Management in the Municipalities of the Republic of Serbia, Lex Localis - Journal of Local Self-Government, 8, 3: $469-486$.

[13] Terzić, D., Popović, V., Malić, N, Ikanović, J, Rajičić, V., Popović, S., Lončar, M \& Lončarević. V. (2019). Effects of long-term fertilization on yield of siderates andorganic matter content of soil in the process of recultivation. The J. Anim. Plant Sci. 29(3).

[14] Radović, M., Vitomir, J. and Popović, S. (2019). The Importance of Implementation of Internal Audit in Enterprises Founded by the Republic of Serbia, Lex Localis - Journal of Local Self-Government, 17, 4: 1001-1011.

[15] Bjelica, B., Bakmaz, O., Mijić, R., Popović, S. and Popović, V. (2017). The implementation of heterogeneous risk to the company's operations and transition countries respecting the behavior of agricultural enterprises in the republic of Serbia. Annals, Economy Series, 3 . 